\title{
Lifelong Learning And The Knowledge Society: Challenges For Developing Countries
}

Naierossadat Daneshvar Hosseini, (E-mail: daneshvar50@yahoo.com), Islamic Azad University, Iran

\begin{abstract}
Economic growth is increasingly driven by knowledge, and no country can remain competitive without applying knowledge. The knowledge economy provides efficient ways to produce goods and services and deliver them more effectively, and at lower costs, to a greater number of people. In addition to the danger of a growing digital gap, there is also a growing knowledge divide. There are striking disparities between rich and poor countries in their investment and capacity in science and technology.
\end{abstract}

Learning and training benefit individuals, enterprises and society alike particularly when based on the needs of the market. Individuals benefit from education and training - provided that these are supported by other economic and social policies. Education and training make individuals employable and help them gain access to better jobs and escape from poverty. Human resources development and training contribute to improved productivity in the economy, reduce skill mismatches in the labor market, and promote a country's international competitiveness

In the $21^{\text {st }}$ century, workers need to be lifelong learners, adapting continuously to changed opportunities and labor market demands of the knowledge economy. Education systems in all countries will have to evolve in that direction. The major challenge of learning and training in the $21^{\text {st }}$ century for developing countries consists of insufficient capability to provide necessary education while also not being market oriented or not based on the needs of the market. These are issues will be discussed in this paper.

\section{INTRODUCTION}

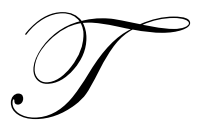

he main driver behind the move towards lifelong learning is the increasing pace of economic change, in technologies, in product and labor markets. In this context, the traditional view of initial education and vocational training, as providing most or all of the skills required for an entire lifetime, has become obsolete. In its place, there is a need for individuals to upgrade their skills on a continuous or lifelong basis. A feature of emerging approaches to lifelong learning is the importance attached to learning and skills acquisition that occurs outside formal educational and training institutions. A major challenge, however, is to develop and extend these new approaches to lifelong learning to make it a reality for all. Instead of restricting lifelong learning to a small, elite group, there is now an expectation that it should involve the entire adult population. For this to occur, new alliances and forms of collaboration between different institutions and the social partners will be required

The issue of acquiring knowledge through lifelong learning for all has become increasing important in all over the world, as globalization and economic integration are making learning and training policies even more important. It is now widely recognized that a well-trained work force is the key to provide firms with a competitive edge. There is a clear need to equip workers with higher and different knowledge and skills to enable them to adapt to accelerating technical and market changes. There is, however, a pressing need to separate rhetoric from reality in this challenge. While much has been said about lifelong learning for all, the concept is still a long way from being a reality for most workers. This paper examines some of the critical elements related to this challenge. 


\section{THE CONCEPTS OF LIFELONG LEARNING AND KNOWLEDGE}

\section{Lifelong Learning}

Based on (ILO 2003), the ILO's constituents agreed upon a number of definitions pertaining to skill, qualifications, employability and lifelong learning. The term "lifelong learning" encompasses all learning activities undertaken throughout life for the development of competencies and qualifications. The term "competencies" covers the knowledge, skills and know-how applied and mastered in a specific context, while the term "qualifications" means a formal expression of the vocational or professional abilities of a worker which is recognized at international, national or sector level. The term "employability" relates to portable competencies and qualifications that enhance an individual's capacity to make use of the education and training opportunities available in order to secure and retain decent work, progress within the enterprise and between jobs and cope with changes in technology and labour market conditions (ILO, 2003, p.8).

OECD provides a broadest possible definition of lifelong learning: i.e. what people learn across their entire lifespan. A recent report on the financing of lifelong learning defined it as it is defined in Islamic terms namely all learning occurring between cradle and grave, from early childhood to the training of people beyond their retirement. A useful distinction is given by the ILO's Report Learning and training for work in the knowledge society, which distinguishes between initial, or pre-employment training which tends to focus on the young, and continuous training or lifelong learning, which emphasize adult learning.

Compared with traditional forms of learning, lifelong learning is different in that it claims to be universal, i.e. covering all citizens across lifecycles and across individuals. The ultimate goal (although nowhere achieved so far) is to give each individual the motivation, the financial means and the physical access to learning at any time in his or her life, so that he or she can develop skills, upgrade or learn new skills for work or for his/her own satisfaction and personal development. The equity, or social, dimension permeates many country specific definitions of lifelong learning as shown by some examples from the Asian region.

\section{Knowledge}

Some western scholars define knowledge as benefiting information which is derived by human senses. John Locke, mentioned that knowledge is something produced through synthesis and empirical activities, and he declined any definition of knowledge without experiments and proves. Alvin Toffler in his writing, The Third Wave defined knowledge as something informative but higher than information This definition is quite close to the definitions by muslim scholars. The debates on knowledge and wisdom (hikmah) have been spread out among our great scholars.

In all the conditions above, we may have a very clear picture that our religious life will never be away from knowledge, its importance and inevitably being part and partial with it. We are not any more talking about the information era, but we have move far into the knowledge era (k-era). Everything in this era must be incorporated with knowledge to be valuable where as knowledge has been the most valued asset in all our life routine. We have left behind agro-era, industrial era, info-era and now are heading within the track of knowledge-era.

\section{THE LIFELONG LEARNING FRAMEWORK}

The lifelong learning framework emphasizes that learning occurs during the entire course of an individual's life. Formal education and training contribute to learning, as do non-formal and informal learning taking place in the home, the workplace, the community and society at large. Its key features are the following: the centrality of the learner, catering to a diversity of learner needs; emphasis on the motivation to learn, e.g. through self-paced, selfdirected and increasingly ICT-assisted learning; the multiplicity of educational and training policy objectives and the recognition that an individual's learning objectives may change over the course of his or her lifetime; and that all kinds of learning - formal, non-formal and informal - should be recognized and made visible. 
According to the ILO, "lifelong learning ensures that the individual's skills and competencies are maintained and improved as work, technology and skill requirements change, ensures the personal and career development of workers; results in increases in aggregate productivity and income; and improves social equity" (ILO 2000a, para. 5).

The draft Recommendation further calls on governments, employers and workers "to renew their commitment to lifelong learning: governments by investing to enhance education and training at all levels; the private sector by training employees; and individuals by making use of the education, training and lifelong learning opportunities..."

Skills have become increasingly important in determining an individual's ability to secure a job, retain employment and move flexibly in the labour market. Although vocational skills remain important, another category has become crucial for the individual's employability. This category has been variously labelled under key and core skills, key competencies, generic skills, etc. These skills differ both in number and type according to the socioeconomic context and time reference. However, there is consensus over the requirement of higher and nonvocational skills that enable the individual to perform at work and in society. In other terms, an individual's employability is the result of a set of vocational and core-work skills that can be transferred between and across occupational sectors.

\section{K-ERA AND LIFELONG LEARNINIG}

$\mathrm{K}$-era exposes us to a competitive world which the core weapon is knowledge. K-society, k-economy, kworkers and other ' $\mathrm{k}$ 's have been part of our life environment. Developing an organization is very much related to developing k-workers rather than concentrating on capital investment as the whole. Workers with k-competencies would be more valued assets to be exploited in developing organization. Most employers dream their workers to be multi-skilled, knowledgeable and may develop the organization using their knowledge. Even in corporative world, we may see some companies establish special unit like competitive intelligence, RnD or whatsoever called which is equivalent to them in order to manage the knowledge competitive power.

This awareness by the employers has led the environment of long life learning, continuous professional education or development, continuous medical education, e-learning, flexible long distance learning and others. Now, the media are there but the question is; how to inculcate the culture of continuous seeking knowledge, sharing knowledge or being responsible in developing k-society.

In addition, the emergence of science and technology has enjoyed remarkable progress that lead to the rapid and exciting paradigm changes. One of the most important factors in this progress is the expertise resulting from specialization, which has enabled human beings to utilize profound and highly detailed stores of knowledge. In order to know and understand these kind of changes, the society now are being motivated to begin searching for answers, with a variety of different people searching in a variety of ways, amassing knowledge in ever-increasing detail.

\section{LIFELONG LEARNING FOR WORK}

While governments in many countries have reasserted their primary governance and policy-making role in promoting lifelong learning polices and programs, actual program and course provision is increasingly done by the private and enterprise sectors. In a large number of countries the private sector is responsible for skills development and lifelong learning on a substantial scale. The State may have dominated the provision of high-profile institutional training. However, the private sector, through innumerable types of learning and training activities, many of them informal and discernible only to those directly involved, may well be making the greater contribution overall.

Expanding access to lifelong learning opportunities is a major concern in most countries. Access to lifelong learning remains limited for various reasons. The opportunities for lifelong learning may not be available; people may lack physical access or the financial means to pay for learning opportunities. Others may be blocked from further learning for lack of recognition of the skills they have gained earlier, formally or informally. People may also lack information about existing courses, programs and opportunities for learning. 
Many private enterprises are investing more and more in lifelong learning and training programs for their employees. Much of this investment is triggered less by government incentives or support than by enterprises' realization that by investing in new skills, upgrading and continuous or lifelong learning of their employees, they are most likely to improve performance and competitiveness. Enterprises are often disillusioned by the (poor) quality of training provided by public institutions. Markets, technologies and work organization undergo continuous change. Goods and services production is becoming increasingly knowledge intensive. In this environment, enterprises increasingly invest more in the skills, knowledge and lifelong learning of their staff than in physical capital. Some firms, particularly in competitive high-technology sectors, spend significant shares of their operating expenses on training staff.

Modern ICTs are revolutionizing learning and training, internationally. From a passive, teacher or trainercentered approach to gaining knowledge and skills, there is a shift towards learning for work and life, centered around the individual. ICTs are used by an increasing number of people as learning tools, since access to them is expanding rapidly in high- and many middle-income countries and free courses are becoming available on the Internet.

\section{KNOWLEDGE AND LIFELONG LEARNING I ISLAM}

Islam is a knowledge basis religion. Muslims believe the first man, Adam which was created by the God has been given the light (nur) of knowledge. It was the obvious advantage owned by human being to differentiate them for other creatures; and had privilege to be appointed as vicegerent of the world. The Holy Quran mentions about knowledge (ilm) 750 times which is equal to about $12.5 \%$ out of the whole Quranic contents; with the first verse has clearly give the picture of it, where Allah says about the importance of knowledge, order to seek it through systematic ways; reading, thinking and writing with the divine objectives.

Read! With the name of the God Who has created. He who created man from a clay. Read! And your God is the most Great. He who teaches (you) with a pen. He who teaches man whatever he is not knowing. (Al Alaq: 1-5)

In this verse, the Holy Quran at its first teaching stressed on the obligation of seeking knowledge, teaching knowledge and sharing knowledge with others who do not know.

\section{CONCLUSIONS AND SOME REFORMS SUGGESTIONS}

Developing countries are at different stages of reforming their systems of education and training to make them meet the challenging ambition of ensuring lifelong learning opportunities for all. The review that follows will outline some of the necessary reforms that will further countries' progress in this area.

All the parties concerned, including the State, the enterprise and individuals, will have to contribute to increased investment in lifelong learning institutions and programs Building the foundations for lifelong learning by emphasizing learning-to-learn skills in particular. With the massive increase in information available today, people must learn to access, select and use information that is relevant to their needs and transform it into knowledge.

A fundamental change in education and training policies and development is necessary in order to ensure that all citizens have access to, and make effective use of, opportunities for lifelong learning. Building a lifelong learning system is not "adding" adult and continuous training at the top of the existing education and training system, but rather a fundamental process of structural adjustment of the entire system of education and training." What goes with effective lifelong learning?

In the $21^{\text {st }}$ century, workers need to be lifelong learners, adapting continuously to changed opportunities and labor market demands of the knowledge economy. Education systems in all countries will have to evolve in that direction. 
Some other recommendations may be as follows:

- $\quad$ traditional education methods are ill suited in providing people with the skills they need

- $\quad$ teacher training needs to change

- $\quad$ formal education institutions need to become more flexible

- $\quad$ the public sector can no longer be the sole provider of education and the private sector should play a greater role in education

- $\quad$ the private and public sectors need to work together to finance learning

\section{BIBLIOGRAPHY:}

1. Ashton, D. and Sung, J. 2002: Supporting workplace learning for high performance working, Geneva, ILO.

2. European Union, 1995: White Paper on Education and Training, Teaching and learning: Towards the learning society.

3. EUROSTAT, 2002: European Social Statistics: Continuing vocational training survey (CVTS2), data 1999, European Communities, Luxembourg.

4. http://www.skillsbase.dfes.gov.uk/Downloads/CVTS2\%20Eurostat\%20report.pdf.

5. Haan, H. C. 2001: Training for work in the informal sector: Evidence from Kenya, Tanzania and Uganda, Turin, International Training Centre of the ILO.

6. Han Soonghee. 2001: Creating systems for lifelong learning in Asia, in Asia Pacific Education Review, vol. 2, no 2. p. 90.

7. Hudson, H. 2001: The potential of ICTs for developments: Opportunities and obstacles, background paper for the ILO's World Employment Report.

8. $\quad$ ILO. 2003: Human resources development and training, Report 92 IV (1), Geneva.

9. $\quad$---. 2002: Learning and training for work in the knowledge society, Report 91 IV (1).

10. OECD. 1996: Lifelong learning for All, Paris.

11. UNESCO. 2003: Good Practices: Gender Equality in Basic Education and Lifelong Learning through CLCs: Experiences from 15 Countries, Bangkok. http://www.unescobkk.org/ips/ebooks /documents/clcgender/index.htm. 


\section{NOTES}

